\title{
KAJIAN PUSTAKA TENTANG APOPTOSIS PADA KEHAMILAN NORMAL DAN ABNORMAL
}

\author{
Zainabur Rahmah \\ Program Studi \\ (Kesehatan Lingkungan)
}

\begin{abstract}
Apoptosis occurs during normal and abnormal pregnancy. Apoptosis has been demonstrated occurs in smooth muscle cell (VSMC) desidual and amniotic membrane. The purpose of this paper is to determine the mechanism of apoptosis of smooth muscle cell (VSMC), decidual and amniotic membrane in normal and abnormal pregnancies. Apoptosis in normal pregnancy VSMC express TRAIL (DR4 and DR5) that cause apoptosis in VSMC associated with remodeling uterine spiral arteries in the first trimester of pregnancy. In the induction of apoptosis in the desidua by steroid hormones such as estrogen, progesterone and hCG improved so that the regulation of FasL in the desidua basalis that play a role in the process of implantation. Apoptosis in the amniotic membrane, there are two paths namely death receptor pathway and mitochondrial pathway.
\end{abstract}

Keywords: Apoptosis, Pregnancy Normal, Abnormal Pregnancy 


\begin{abstract}
ABSTRAK
Apoptosis terjadi selama kehamilan normal dan abnormal. Apoptosis telah ditunjukkan terjadi di dalam smooth muscle cell (VSMC) membran desidua dan membran amnion. Tujuan dari makalah ini adalah untuk menentukan mekanisme apoptosis smooth muscle cell (VSMC), desidua dan membran ketuban pada kehamilan yang normal dan abnormal. Apoptosis pada kehamilan normal VSMC mensekpresikan TRAIL (DR4 dan DR5) yang menyebabkan apoptosis pada VSMC terkait dengan renovasi arteri spiralis uterus pada trimester pertama kehamilan. Apoptosis pada desidua diinduksi oleh hormon steroid seperti estrogen, progesteron dan hCG sehingga meningkatkan regulasi FasL dalam desidua basalis yang memainkan peran dalam proses implantasi. Apoptosis pada membran ketuban ada dua jalur yaitu jalur kematian reseptor dan jalur mitokondria.
\end{abstract}

Kata kunci: Apoptosis, Kehamilan Normal, Kehamilan Abnormal

\section{PENDAHULUAN}

\section{Latar Belakang}

Apoptosis berasal dari bahasa Yunani apo $=$ "dari" dan ptosis = "jatuh", yaitu mekanisme biologi berupa kematian sel yang terprogram. Apoptosis digunakan oleh organisme multi-seluler untuk membuang sel yang sudah tidak diperlukan oleh tubuh. Apoptosis berbeda dengan nekrosis. Apoptosis pada umumnya berlangsung seumur hidup dan bersifat meng-untungkan bagi tubuh, sedangkan nekrosis ada-lah kematian sel yang disebabkan oleh kerusakan sel secara akut. Bila sel kehilangan kemampuan melakukan apoptosis maka sel tersebut dapat membelah secara tak terbatas dan akhirnya menjadi kanker (Parslow et al., 2001).

Proses apoptosis atau program kematian sel yang berjalan bersama dengan proliferasi sel dan diferensiasi memainkan peran penting selama embriogenesis normal (Joswig et al., 2003). Hal ini dapat dibuktikan bahwa pada kehamilan yang mengalami komplikasi dan terjadi anomali struktural bawaan memang didahului oleh apoptosis yang berlebihan pada jaringan embrio dan ekstra-embrio (Toder et al., 2002). Telah dibuktikan bahwa apoptosis yang terjadi pada sel otot polos vaskuler foascular smooth muscle cell, desidua, dan sel epitel membran amnion pada kehamilan yang bertanggung jawab untuk pertumbuhan dan remodeling jaringan, dan keseimbangan antara proliferasi dan diferensiasi sel (Smith et al., 1997).

Terjadinya kehamilan sampai terjadi kelahiran bayi berhubungan dengan proses ke-matian sel yang terprogram yang disebut apop-tosis. Hal ini dibuktikan dari penelitian yang pernah dilakukan, bahwa derajat apoptosis sel otot polos vaskuler foascular smooth muscle cell, desidua (Runic et al ., 1998; Helwing and Bou-teller, 2007) dan membran amnion (Kumagai et al., 2001) berfluktuasi sesuai dengan usia dan kondisi kehamilan (Norwitz, 2001).
Indeks apoptosis pada vasculer smooth muscle cell dan desidua manusia pada kehamilan usia 3742 minggu lebih tinggi dibandingkan pada usia kehamilan 23-30 minggu (Runic et al., 1998) dan persentase apoptosis pada epitel membran amnion manusia tertinggi terjadi di usia 40-41 minggu dibandingkan dengan usia 16-27 minggu (Kumagai et al., 2001). Hal ini diperkuat dengan bukti bahwa derajat apoptosis sel plasenta bayi aterm yang lahir spontan tidak berbeda bermakna dengan plasenta bayi aterm yang lahir melalui tindakan operasi caesar (Thiet et al., 2000). Apoptosis juga memegang peranan penting dalam perkembangan kehamilan normal maupun patofisiologi kehamilan yang terganggu akibat penyakit (Goltein, 1997).

Secara fisiologis proses apoptosis digunakan oleh tubuh sebagai salah satu mekanisme homeostasis misalnya organogenesis sehingga pada akhirnya akan terbentuk organ yang sempurna fungsinya. Apoptosis di vascular smooth muscle cell, desidua dan sel epitel membran amnion adalah salah satu contoh proses apoptosis yang terus diperlukan sepanjang kehamilan normal sampai saat yang tepat janin lahir sebagai bayi. Kegagalan kehamilan atau berakhirnya kehamilan sebelum waktunya pada dasarnya disebabkan peningkatan apoptosis di vascular smooth muscle cell, desidua, dan sel epitel membran amnion yang terjadi baik karena adanya faktor ekstrinsik seperti infeksi maupun faktor-faktor sistemik yang saling berpengaruh satu dengan yang lain.

\subsection{Rumusan Masalah}

Berdasarkan latar belakang yang telah diuraikan diatas, maka dikemukakan rumusan masalah sebagai berikut :

Bagaimanakah mekanisme apoptosis vascular smooth muscle cell, desidua, dan membran amnion pada kehamilan normal dan abnormal? 


\subsection{Tujuan}

Makalah ini bertujuan untuk mengetahui mekanisme apoptosis vascular smooth muscle cell, desidua, dan membran amnion pada kehamilan normal dan abnormal.

\section{TINJAUAN PUSTAKA}

\subsection{Proses Perkembangan dan Kematian Sel}

Sel merupakan unit terkecil dalam kehidupan atau yang menyusun jaringan tubuh organisme (Campbell et al., 2000). Organisme multiseluler yang kompleks seperti manusia dapat hidup dilingkungan yang mempunyai kemampuan mempertahankan keadaan di dalamnya. Upaya mempertahankan keadaan lingkungan yang stabil disebut homeostasis yang berasal dari kata yunani homeo (sama) dan stasis (mempertahankan keadaan lingkungan) (Siagian, 2004).

Kematian sel diciptakan oleh sel itu sendiri agar bertahan hidup pada kondisi normal. Proses inilah yang memungkinkan tubuh bisa melepaskan diri dari sel-sel yang mengalami kerusakan. Oleh karena itu, program kematian dan program kehidupan bekerja secara bersamaan dalam tubuh manusia dan benda hidup lainnya. Hebatnya kematian sel yang diprogram, memerankan peranan penting dalam sistem kekebalan tubuh. Andai saja tidak ada program kematian sel, tentu tubuh tidak mampu melawan penyakit. Bahkan proses ini menguasai proses perlindungan tubuh saat terkena inflamasi yang bermacam-macam, sehingga tubuh bisa melepaskan sel-sel yang jika masih hidup, akan menyebabkan penyakit (Parslow et al., 2001).

\subsection{Nekrosis dan Apoptosis}

Nekrosis adalah kematian sel yang terjadi pada organisme sebagai akibat dari adanya kerusakan sel akut atau trauma (misalnya: kekurangan oksigen, perubahan suhu yang ekstrem, dan cedera mekanis). Kematian sel karena nekrosis terjadi secara tidak terkontrol yang dapat menyebabkan rusaknya sel ditandai adanya respon inflamasi dan sangat berpotensi menyebabkan masalah kesehatan yang serius (Jacobson et al., 1999).

Apoptosis adalah program kematian sel yang secara aktif menginduksi kematian untuk dirinya sendiri (Campbell et al., 2000). Proses apoptosis merupakan mekanisme fisiologis yang dimulai tanpa gejala inflamasi dan melibatkan penggunaan energi serta sintesis aktif pada protein. Apoptosis terjadi selama perkembangan normal sel dan penting bagi keseimbangan yang tepat dalam pembentukan jaringan dan organ-organ tertentu. Apoptosis berperan dalam mekanisme biologis seperti perkembangan, pemeliharaan dan perbaikan jaringan. Pada hewan dalam proses perkembangannya apoptosis berperan untuk menetapkan arsitektur jaringan (Yuan and Yankner, 2000), sedangkan dalam sistem imun apoptosis berperan dalam regulasi/pematangan limfosit, dan homeostasis (Green, 2003).

Apoptosis memiliki ciri morfologis yang khas seperti blebbing membran plasma, pengerutan sel, kondensasi kromatin dan fragmentasi DNA, kehilangan hubungan normal antar sel, dan pembentukan badan-badan apoptotik. Sel segera difagosit dan dimakan oleh sel-sel tetangga dan makrofag. Pada proses apoptosis sel tidak mengeluarkan isi sel ke daerah antar sel sehingga tidak dapat menyebabkan inflamasi (Hengartner, 2000). Tabel 1 berikut menjelaskan perbedaan antara apoptosis dan nekrosis.

\section{PEMBAHASAN}

\subsection{Peran Apoptosis Pada Kehamilan Normal dan Abnormal}

Apoptosis pada vascular smooth muscle cell, desidua dan membran amnion yang terjadi selama kehamilan berlangsung sudah banyak diteliti oleh para ilmuwan (Runic et al., 1998). Vascular smooth muscle cell, desidua, dan membran amnion manusia mengalami apoptosis selama kehamilan berlangsung dan berhubungan dengan kelahiran. Pada trimester awal kehamilan terjadi apoptosis sel-sel $\mathrm{T}$ desidua bertujuan untuk memelihara penyesuaian sistem imun yaitu pertahanan diri terhadap penolakan alograf janin oleh sistem kekebalan ibu (De Luca et al., 2005).

Selama kehamilan normal diendometrium ditempat implantasi, jumlah makrofag 20-30\%, dan tetap tinggi selama kehamilan berlangsung (Mor et al., 2005). Gambar 1 menunjukkan Per-bedaan distribusi makrofag dan produksi sitokin pada kehamilan normal dan abnormal (IUGR/preeklamsi). 


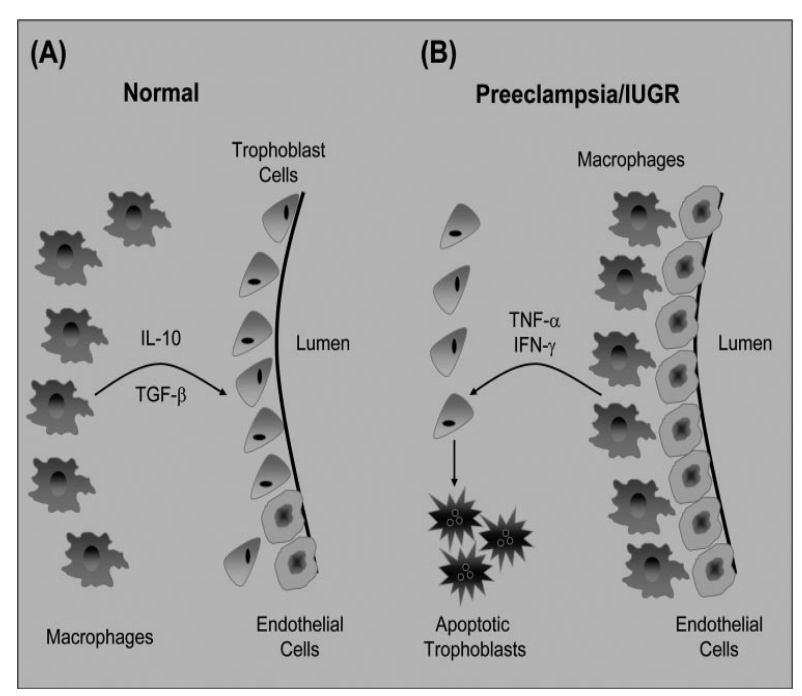

Gambar 1. Perbedaan Distribusi Makrofag dan Produksi Sitokin pada Kehamilan Normal dan Abnormal (IUGR/preeklamsi).

(A). Pada kehamilan normal sel-sel makrofag mendukung kehidupan trofoblas dengan memfasilitasi invasi trofoblas dan arteri spiralis

(B). Pada kondisi patologis seperti preeklamsi/ IUGR, makrofag berfungsi sebagai penghalang pada waktu invasi trofoblas dengan menginduksi apoptosis trofoblas Sumber (Mor et al., 2005).

Pada kehamilan normal, sel endotel uterus mengalami apoptosis. Sel-sel apoptosis ini menginduksi makrofag untuk memproduksi sitokin Th2 seperti IL-10, IL-6, IL-4 dan TGF-â yang bersifat anti-inflamasi dan Immunosupresi dan menekan sekresi sitokin Th1. Suasana lingkungan ini menyebabkan kelangsungan kehidupan trofoblas seperti Gambar 2 yaitu pada kehamilan normal sel-sel makrofag mendukung dengan memfasilitasi invasi trofoblas dan arteri spiralis. Pada kehamilan yang mengalami komplikasi seperti preeklamsi, makrofag mensekresikan sitokin proinflamasi seperti TNF-á dan IFNã dan menyebabkan apoptosis sel trofoblas ekstravilous (Mor et al., 2005).

Kondisi lokal ditempat implantasi ditentukan oleh faktor-faktor terlarut yang diproduksi ditempat itu. Studi pada manusia dan tikus menunjukkan bahwa Leukemia inhibitory factor (LIF), IL-1, IL-6, IL-11, heparin-binding epidermal growth factor (HB-EGF), TGF-â, sel denritik dan IL-17 berperan penting pada proses implantasi dengan memodulasi proses angiogenesis, diferensiasi trofoblas dan sistem imun (Yoshinaga, 2008).

Interleukin 17 merupakan sitokin proinflamasi yang berperan penting pada induksi inflamasi dan diperlukan pada awal kehamilan untuk proses implantasi. Inflamasi yang berlebih- an menyebabkan janin mengalami aborsi Sel Treg diketahui dapat berfungsi mengontrol terjadinya inflamasi yang berlebih dan menghambat proliferasi dan produksi oleh $\mathrm{CD}^{+}$dan $\mathrm{CD}^{+}$ (Arruvito et al., 2007).

Hubungan timbal balik antara sel Th17 dan sel Treg di daerah perifer dan desidua dapat dikontrol oleh IL-6. IL-6 merupakan sitokin yang menghambat perkembangan sel Treg dan menginduksi diferensiasi Th-17 temuan ini menunjukkan bahwa IL-6 berperan penting dalam peningkatan Th-17. Peningkatan IL-1 dan IL-6 dan penurunan produksi TGF-â menyebabkan peningkatan Th-17 dan penurunan sel Treg di dalam rahim (Arruvito et al., 2007).

\subsubsection{Apoptosis pada Vascular Smooth Muscle Cell}

Apoptosis atau kematian sel terprogram adalah mekanisme alami tubuh untuk menghilangkan yang tidak perlu atau berpotensi berbahaya dan untuk mempertahankan fungsi jaringan normal. Selama implantasi apoptosis berperan penting untuk terjadinya remodeling jaringan pada desidua ibu dan invasi trofoblas pada perkembangan embrio (Krussel, et al., 2003)

Keberhasilan proses implantasi tergantung pada sinkronisasi antara tahap perkembangan embrio dan rangkaian peristiwa molekuler dan seluler di dalam rahim ibu (Krussel, et al., 2003). Proses implantasi terjadi mulai hari keenam sampai ketujuh setelah pembuahan (Vigano, et al., 2003) dan pada dasarnya terdiri-dari tiga tahap, yaitu (1) Aposisi yang menunjukkan adhesi awal, masih stabil, dan merupakan adhesi blatokista ke sel desidua (2). Adhesi yang stabil menunjukkan adhesi antara blatokista ke epitel uterus (3). Proses invasi yang di mulai dengan penetrasi sinsitiotofoblas melalui epitel uterus dan diikuti oleh infiltrasi mononuclear sitotrofoblas masuk ke dalam endometrium dan pembuluh darah uterus. Hal ini menunjukkan sel trofoblas berada kontak langsung dengan darah ibu dan membentuk sirkulasi uteru plasenta (Norwitz, et al., 2001).

Pada trimester pertama dari kehamilan manusia, dinding pembuluh darah mengalami remodelling melalui perubahan degeneratif yang mengubah arteri spiralis rahim yang terletak di dalam desidua basilis menjadi datar Arteri terbuka lebar, sehingga memungkinkan suplai darah berlimpah ke daerah pertukaran feto-maternal dalam plasenta. Telah diketahui bahwa sitotrofoblas ektravillus berasal dari sitotrofoblas janin yang bermigrasi ke dalam segmen dinding arteri spiralis melalui jalur endovaskuler dan jalur migrasi intertisial ke desidua basalis untuk memicu 
hilangnya endotel dan vasculer smooth muscle cell (VSMC). Pada proses ini sel trofoblas tertimbun di dalam lapisan fibrinoid yang menggantikan lapisan medial otot di desidua. Invasi trofoblas menyebabkan ujung arteri spiralis menjadi pembuluh darah yang melebar dan dapat mengalirkan darah ibu ke janin lebih banyak di dalam plasenta ditunjukkan seperti Gambar 3A (Pijnenborg et al., 2006).

Pada waktu implantasi terjadi apoptosis pada vascular smooth muscle cell (VSMC)/sel otot polos vaskuler. Terjadinya apoptosis dipicu oleh signal parakrin berasal dari trofoblas. Apoptosis pada sel trofoblas di bagi menjadi dua jalur yaitu jalur intrinsik mitokondria yang mengikat membran death receptor dari tumor necrosis reseptor family dan jalur ekstrinsik yang menginduksi apoptosis pada sel (Redman and Sargent, 2005).

Proses apoptosis pada sel trofoblas dapat di jelaskan sebagai berikut : tumor necrosis receptor family death receptor atau dikenal sebagai reseptor Fas mengikat ligan kognitifnya yaitu FasL muncul dalam ruang ekstraseluler, menginduksi reseptor trimerisasi dan mengikat adaptor protein FADD (Fas Associated Death Domain) kebagian intraseluler dari reseptor Fas. Fas/FADD kompleks mengkonversi procaspase 8 menjadi caspase 8 aktif yang selanjutnya mengaktifkan downstream caspase yang pada akhirnya menyebabkan pembelahan DNA dan pembelahan protein seluler. Apoptosis dipicu oleh terlepasnya cairan FasL dari invasi trofoblas dapat berkontribusi pada hilangnya sel endotel VSMC dari dinding arteri spiralis (Kimberley and Screaton, 2004). Sel trofoblas juga mengekspresikan Tumor necrosis factor apoptosis inducing ligand (TRAIL) yang menyebabkan apoptosis pada VSMC. Gambar 2 menunjukkan skematis yang menggambarkan invasi trofoblas pada arteri spiralis perjalanan dari miometrium ke desidua basalis.

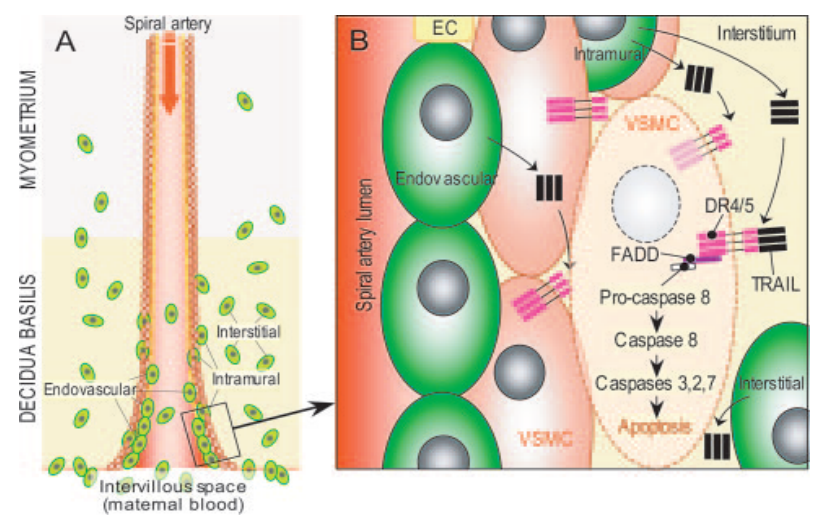

Gambar 2 : Skematis yang Menggambarkan Invasi Trofoblas pada Arteri Spiralis Perjalanan dari Miometrium ke Desidua Basalis.
(A) Sel trofobals berasal dari ruang interviluos menginvasi arteri spiralis melalui intertisial atau endovaskuler. Pada bagian arteri spiralis yang terbuka luas di ruang intravillous, trofoblas endovaskuler mengambil tempat endothelium dan intramular trofoblas meng-ambil tempat pada VSMC (B). Sel trofoblas melepaskan TRAIL yang mengikat VSMC trimeric death receptors 4 dan 5 (DR4/5), yang mempromosikan pengrekrutan protein FADD. FADD mengikat dan membelah procaspase 8 diaktifkan menjadi caspase 8 . Hal ini memicu aktivasi kaskade caspase yang akhirnya menyebabkan apoptosis VSMC (Helwig and Bouteller, 2007)

Selama proses implantasi terjadinya remodelling arteri spiralis di desidua terdapat peran sel uterine natural killer (uNK). Sel ini jumlahnya me-ningkat di desidua selama kehamilan (Redman and Sargent, 2005). Peran sel uNK selama remodelling arteri spiralis yaitu (1), sel uNK berperan pada remodeling vascular smooth muscle cell(VSMC)/ sel otot polos vaskuler (Croy et al., 2003) (2), sel uNK memproduksi sitokin interferon ã yang berpartisipasi pada modifikasi arteri spiralis (Ashkar et al., 2000). Sel uNK juga melepaskan IL-8 yang berfungsi mengontrol invasi trofoblas pada desidua basalis (Le Bauteiller and Tabiasco, 2006).

Studi pada manusia dan tikus menunjukkan bahwa IL-6, IL-11, TGF-â, LIF, dan IL-1 berperan penting untuk implantasi dengan memodulasi proses angiogenesis dan diferensiasi trofoblas (Yoshinaga, 2008). IL-1 terdapat pada interaksi feto-maternal, diproduksi oleh sel trofoblas dan sel stroma desidua dan menjadi salah satu sinyal pertama pada blatokista yang melakukan invasi ke endometrium. Interleukin-1 juga dapat menginduksi sel trofoblas mengalami apoptosis selama proses implantasi dan menginduksi aktivitas MMP-9 dalam trofoblas sehingga mendorong invasi trofoblas ke endometrium (Simon, et al., 1994).

\subsubsection{Apoptosis pada Desidua}

Selama kehamilan makrofag dan sel limfosit tinggi di interaksi feto-maternal. Large granular limfosit, limfosit T, dan makrofag terdiri-dari 70, 20, dan $10 \%$ dari populasi leukosit yang terdapat di desidua (Loke and King, 1995). Selama terjadi invasi trofoblas ke desidua sistem imun mengalami supresi sehingga terjadi toleransi pada janin (Giffith et al., 1995). Pada trimester awal kehamilan juga terjadi apoptosis sel $\mathrm{T}$ di desidua yang bertujuan untuk penyesuaian sistem imun yaitu pertahanan diri terhadap penolakan alograf janin oleh sistem imun ibu (De Luca et al., 2005). 
Hormon steroid ibu memiliki peran penting dalam pembentukan desidua endometrium selama kehamilan. Selam et al (2001), telah menunjukkan bahwa siklus regulasi tergantung pada ekspresi FasL dalam endometrium manusia, dan bahwa FasL regulasinya di tingkatkan oleh hormon estrogen dan progesteron dalam sel stroma dan endometrium (Galan et al., 2000). Apoptosis sel glandular meningkat pada waktu terjadi implantasi, menunjukkan bahwa apoptosis berperan penting selama proses implantasi manusia (Rogerson et al., 1998).

Selama implantasi hormon human chorionic gonadotropin (hCG) yang dihasilkan oleh trofoblas berperan dalam imunotoleransi ibu pada janin, dan menginduksi terjadinya apoptosis di desidua oleh regulasi Fas-FasL (Kayisli et al., 2003). Regulasi FasL ditingkatkan oleh hCG dalam endometrium manusia dapat memiliki beberapa peran dalam implantasi yang salah satu peran potensial yaitu menstimulasi apoptosis sel stroma sehingga memungkinkan invasi trofoblas ke dalam endometrium. Diferensiasi dan apoptosis sel stroma dan kelenjar selama decidualisasi dari endometrium sangat penting untuk mengkontrol invasi trofoblas dan interaksi dengan pembuluh darah ibu (Bellgrau et al., 1995)

Selama implantasi sistem imun ibu mengalami supresi sehingga terjadi toleransi pada antigen paternal (Tafuri et al., 1995; Hunt et al., 1997). Hal ini di mediasi oleh sel trofoblas yang mengekspresikan HLAG dan ekspresi FasL oleh sel desidua (Rossant and Cross, 2001). Banyak mekanisme yang melindungi janin dari sistem imun ibu diantara yaitu ekspresi molekul MHC nonclassical (Ishitani et al., 2003). Sel plasenta dan desidua menghasilkan katabolisme triptofan oleh enzim IDO (indolamine 2,3-dioxygenase) (Munn et al., 1998), apoptosis sel T (Hunt et al., 1997). Studi terbaru juga mendokumentasikan peran sel T regulatory (Tregs) (Somerset et al., 2004). Interaksi antara berbagai mekanisme pada imunosupresi/toleransi fetomaternal di tunjukkan seperti
Gambar 3.

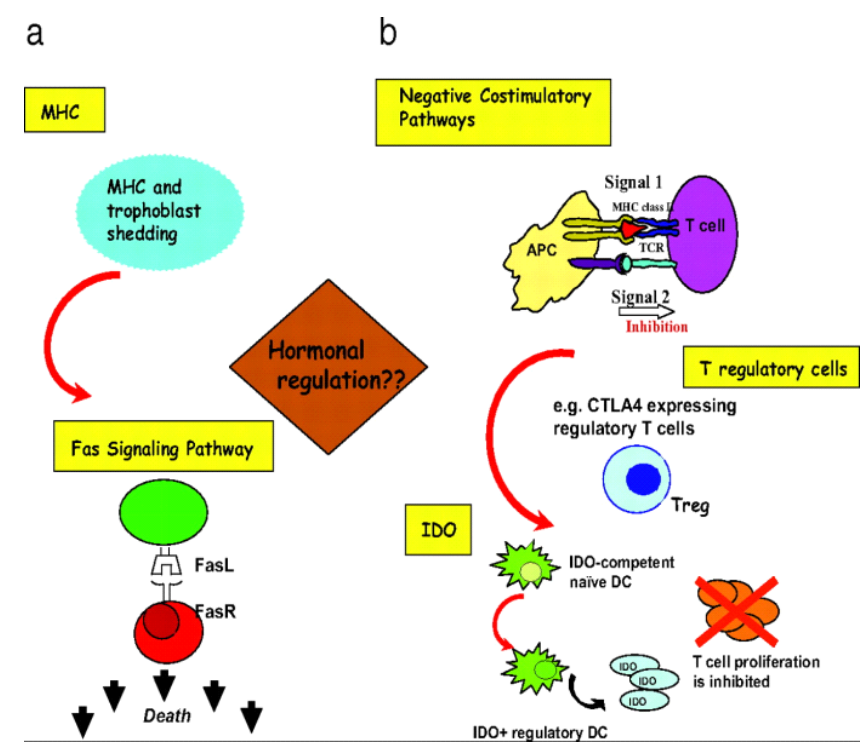

Gambar 3. Interaksi antara Berbagai Mekanisme pada Imunosupresi/Tole-ransi Feto-maternal

Interaksi antara beberapa mekanisme pada toleransi Feto-maternal. a, MHC berasosiasi dengan HLA-G bisa menyebabkan apoptosis sel $\mathrm{T}$ alogenik melalui jalur- Fas FasL. b, Tregs merupakan komponen penting dalam pemeliharaan toleransi perifer ke jaringan-spesifik self-Ags Tregs dapat menginduksi DC naif untuk menghasilkan IDO disebut sebagai IDO ${ }^{+}$regulatory DC. IDO dapat menghambat proliferasi sel $\mathrm{T}$ oleh catabolizing triptofan (Guleria et al., 2007).

\subsubsection{Apoptosis pada Sel Epitel Membran Am- nion}

Penelitian tentang apoptosis sudah banyak dilakukan pada jaringan berbagai reproduksi, seperti endometrium (Yamashita et al, 1999.), ovarium folikel atretik (Tilly et al, 1991.) dan plasenta (Levy dan Nelson, 2000). Apoptosis juga dilaporkan terjadi di membran amnion janin tikus (Lei et al., 1999) dan di membran amnion manusia (Kumagai et al., 2001).

Beberapa penelitian tentang apoptosis di endometrium manusia menunjukkan adanya ekspresi Fas dan FasL (Yamashita et al., 1999) dan ekspresi siklik dari Bcl-2 memuncak pada fase proliferatif (Tabibzadeh et al.,1995) keduanya sangat terkait dengan apoptosis dalam endometrium manusia juga ekspresi Bcl-2 pada trofoblas manusia, dalam kaitannya dengan deposisi fibrin (Marzioni et al., 1998). Selama kehamilan sel epitel membran amnion ruptur pada waktu terjadi apoptosis tidak meng-ekspresikan Bcl-2 (McLaren et al, 1999). Selama kehamilan normal menunjukkan bahwa persentase sel apoptosis pada epitel 
amnion manusia tertinggi terjadi di usia 40-41 minggu dibandingkan dengan usia 16-27 minggu (Kumagai et al., 2001). Sebaliknya pada kehamilan dengan komplikasi persentase apoptosis pada epitel amnion tertinggi pada usia 23-30 minggu di bandingkan pada usia 37- 42 minggu (Runic et al., 1998).

Mekanisme apoptosis pada sel epitel membran amnion dapat ditunjukkan pada Gambar 5 apoptosis pada sel epitel membran amnion di bagi menjadi 2 jalur yaitu : death reseptor dan jalur mitokondria. (1). Jalur death reseptor melibatkan Fas, sebuah tipe I membran protein termasuk tumour necrosis factor (TNF) reseptor/receptor family (Nagata and Golstein, 1995), dan ligan Fas (FasL) dan protein adaptornya (FADD). Pengikatan FasFasL menginduksi clustering reseptor dan pembentukan death-inducing signaling complex. FasL terikat pada membran dirubah ke bentuk FasL terlarut/soluble oleh aksi dari matrix metalloproteineses (MMP) (Tanaka et al., 1996). Penelitian menunjukkan aktivasi matrix metalloproteineses (MMP) meningkat pada sel epitel membran amnion aterm (MacLaren et al., 2000). Beberapa molekul procaspase- 8 menghasilkan aktivasi caspase-8. Diaktifkannya caspase- 8 memotong/ Cleaves procaspase-3 untuk mendapatkan bentuk aktif. ownstream/penurunan dari caspase-3 menginduksi pembongkaran dan degenerasi produksi aktin, DNase, dan lamins (Cohen, 1997). (2). Jalur mitokondria dimulai dari pelepasan sitokrom c dari ruang antar membran mitokondria. Pada waktu terjadi pelepasan sitokrom $\mathrm{c}$ dia tidak mengekspresikan Bcl2 tetapi mengekspresikan Bax. Sitokrom c kemudian diasosiasikan dengan Apaf1 dan procaspase 9 mengaktifkan caspase 9 dan 3. Aktifasi caspase 3 dan 8 terus bertambah berbanding lurus dengan usia kehamilan. Dengan aktifnya caspase 3 dan 8 menyebabkan terjadinya DNA fragmentasi dan kondensasi kromatin di nucleus sel epitel mambran amnion (Kumagai et al., 2001).

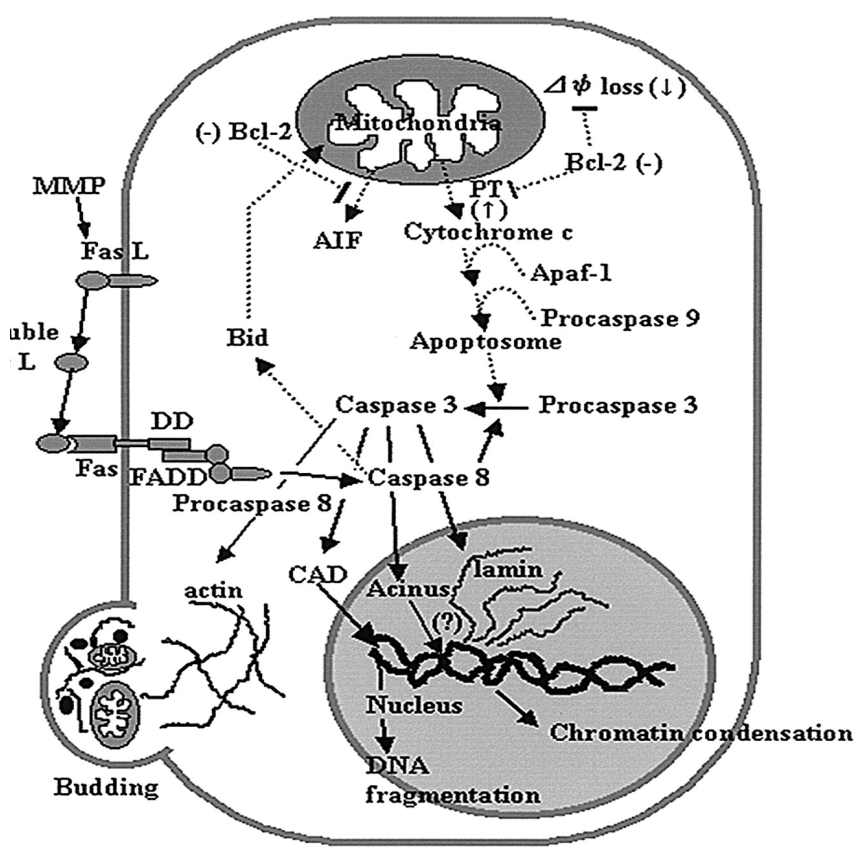

Gambar 4 : Jalur Sinyal Apoptosis pada Membran Amnion Aterm Manusia. (Sumber : Kumagai et al., 2001).

Keterangan : PT : Permeability transition, AIF : Apoptosis Inducing Factor, CAD : Cas-pase Activated DNase; DNA : Dinucleotida Acid; FADD; Associated death domain; DD : Death domain.

\section{KESIMPULAN}

Pada dasarnya apoptosis pada vascular smooth muscle cell, desidua dan membran amnion sama yaitu terdiri-dari dua jalur yaitu jalur reseptor dan jalur intrinsik. Selama kehamilan normal sel makrofag yang berada di desidua mendukung kehidupan trofoblas dengan memfasilitasi invasi trofoblas pada arteri spiralis. Pada kehamilan abnormal atau yang mengalami komplikasi seperti preeklamsi, makrofag mensekresikan sitokin proinflamasi sehingga menyebabkan apoptosis sel trofoblas.

\section{DAFTAR PUSTAKA}

Arruvito L; Sanz M; Banham AH; Fainboim L. 2007. Expansion of CD4+CD25+ and FOXP3+ Regulatory T Cells During the Follicular Phase of the Menstrual Cycle: Implications for Human Reproduction. J Immunol; 178:2572-2578.

Ashkar AA; Di Santo JP; Croy BA. 2000. Interferon Gamma Contributes to Initiation of Uterine Vascular Modification, Decidual Integrity, and Uterine Natural Killer Cell Maturation During Normal Murine Pregnancy. J Exp Med.192:259 -270. 
- Joswig A; Gabriel HD; Kibschull M; Winterhagen E. 2003. Apoptosis in Uterine Epithelium and Decidua in Response to Implantation: Evidence for Two Different Pathways. Reprod Biol Endocrinol; 26(1): 44-53.

- Kayisli, UA; Selam, B; Kayisli-Ozlem Guzeloglu; Demir R; Arici, A. 2003. Human Chorionic Gonadotropin Contributes to Maternal Immunotolerance and Endometrial Apoptosis by Regulating Fas-Fas Ligand System. J Immunol 2003;171;2305-2313.

- Krussel JS; Bielfeid P; Polan ML; Simon C. 2003. Regulation of Embryonic Implantation. European Journal of Obstetrics and Gynecology and Reproductive Biology. 110:2-9.doi:10.1016/ S0301-2115(03)00167-2.

- Kumagai, K; Otsuki, Y; Ito, Y; Shibata, MA; Abe $H$; Ueki, M. 2001. Apoptosis in the normal human amnion at term, independent of Bcl-2 regulation and onset of labour. Molecul Human Reproduction. Vol.7, No.7 pp. 681-689.

- Kimberley FC, Screaton GR. 2004. Following a TRAIL: update on a ligand and its five receptors. Cell Research;14:359 -372.

- Le Bouteiller P; Tabiasco J. 2006. Killers Becomes Builders During Pregancy. Nat Med. 12:991-992.

- McLaren, J; Taylor, D.J; Bell, S.C. 2000. Increased Concentration of pro-matrix Metalloproteinase 9 in term Fetal Membranes Overlying the Cervix Before Labor: Implications for Membrane Remodeling and Rupture. Am. J. Obstet. Gynecol., 182, 409-416.

- Mor G; Abraham VM; Chavez S; L Shawn. 2005. The Role of Apoptosis in the Regulation of Trophoblast Survival and Differentiation During Pregnancy. Reproductive Biology and Endocrinology. 26(7): 877-897.

- Munn, DH; Zhou, M; Attwood, JT; Bondarev, I; Conway, SJ; Marshall, B; Brown, C; Mellor, AL. 1998. Prevention of Alogeneic Fetal Rejection by Tryptophan Catabolism. Science 281: 1191-1193.

- Nagata, S. and Golstein, P.1995. The Fas Death Factor. Science, 267, 1449-1456.

- Norwitz ER; Schust DJ; Fisher SJ. 2001. Implantation and Survival of Early Pregnancy. N Engl J Med. 345:1400-1408.doi: 10.1056/ NeJMra000763.

- Parslow TG; Stites DP; Terr AI; Imboden JB. 2001. Medical Immunology. $10^{\text {th }}$ ed. University of California San Francisco.

- Pijnenborg R; Vercruysse L; Hanssens M. 2006. The Uterine Spiral Artery in Human Pregnancy Facts and Controversies. Placenta.;27:939-958.

- Redman CW; Sargent IL. 2005. Latest Advances in Understanding Preeclampsia. Scienc. 308:1592-1594.

- Runic, R; Lockwood, C.J; LaChapelle, L. 1998. Apoptosis and Fas Expression in Human Fetal Membranes. J. Clin. Endocrinol. Metab., 83, 660-666.

- Rogerson SJ; Pollina E; Getachew A; Tadesse E; Lema VM. 2003. Placental Monocyte Infiltrates in Response to Plasmodium falciparum Malaria Infection and their Association with Adverse Pregnancy outcomes. Am J Trop Med Hyg 68: 115-119.

- Simon C; Frances A; Piquette GN; Danasouri EL; Zurawski G; Dang W;Polan ML. 1994. Embryonic Implantation in Mice is Blocked by Interleukin-1 Receptor Antagonist. Endocrinology; 134: 521-528. Doi: 10.12/en.124.2.521.

- Siagian,M. 2004. Homeotasis. Departemen Ilmu Faal. Fakultas Kedokteran Universitas Indonesia.

- Somerset, DA; Zheng, Y; Kilby, MD; Sansom, DM; Drayson, MT. 2004. Normal Human Pregnancy is Associated with an Elevation in the Immune Suppressive CD25_CD4_ Regulatory T Cell Subset. Immunology 112: 38-43.

- Smith SC; Baker PN; Symonds MD. 1997. Placental Apoptosis in Normal Human Pregnancy. Am J Obstet Gynecol;177(1): 57-65.

- Tanaka, M; Suda, T; Haze, K. 996 Fas ligand in human serum. Nature Med., 2, 317-322.

- Toder V; Carp H; Fein A; Torchinsky A. 2002. The role of Pro- and Antiapoptotic Molecular Interaction in Embryonic Maldevelopment. Am J Reprod Immunol; 48(4): 235-44.

- Thiet MP; Suwanvanichkji V; Hasselblatt K; Yeh J. 2000. Apoptosis in Human Term Placenta: A Morpholgical and Gene Expression Study. Gynecol Obstet Invest 50:88-91.

- Vigono P; Mangioni S; Pompei F; Chiodo I. 2003. Maternal-Conceptus Cross Talk- A Review Placenta. 24:S56-S61. Doi:10.1016/S01434004(03)00137-1.

- Yamashita, H; Otsuki, Y; Ito, Y. 1999. Fas ligand, Fas Antigen and Bcl-2 Expression in Human Endometrium During the Menstrual cycle. Mol. Hum. Reprod., 5, 358-364.

- Yoshinaga K. 2008. Review of Factors essential for Blastocyst Implantation for Their Modulating Effect on The Maternl Immune System. Semin Cell Dev Biol. 19: 161-169.

- Yuan J and Yankner BA. 2000. Apoptosis in the Nervous System. Nature. 407(6805): 802-9. 